Ивлева Наталья Николаевна

учитель начальных классов

МАОУ «СОШ №112 с углубленным изучением информатики» г. Новокузнецк, Кемеровская область

\title{
ОДАРЕННЫЕ ДЕТИ В НАЧАЛЬНОЙ ШКОЛЕ
}

Аннотация: в статье описаны проблемь обучения одаренных детей в начальной школе. Автор рассматривает работу педагога с одаренными детьми.

Ключевые слова: начальная икола, одаренные дети.

Как правило, родители первыми замечают одаренность своего ребенка, это не всегда легко сделать, так как нет стереотипа, который бы определят одаренность ребенка - каждый ребенок проявляет её по- своему. Человек, который имеет более развитые способности, другой по восприятию окружающего мира и другой по характеру. Он не как все строит взаимоотношения с окружающими его людьми, по - другому трудится. Чаще одаренными мы называем детей, опережающих свое развитие в отличие от сверстников. Есть и другая сторона одаренности, трудная для учителей, для родителей. Это одаренность нестандартным мышлением и видением. При этом у ребенка могут быть не такое и выдающиеся способности к усвоению, поэтому это мешает угадать дар ребенка. Ростки одаренности есть в каждом, они дают возможность развивать свой дар и возможность творить. Е. Еремкин говорил, что наличие одаренности является нормой для любого человека, а её отсутствие связано с неверным воспитанием, образованием и развитием. Развитие духовного мира ребенка и взрослого - это единственный путь, ведущий к проявлению таких способностей человеческой природы, какими являются одаренность, талант...

Благоприятным периодом накопления багажа знаний является младший школьный возраст. В этом возрасте дети подчиняются авторитету, они впечатлительны, восприимчивы. Все что они делают, воспринимают как игру. Их способности развиваются динамично и это специфика возраста. 
Одаренные в одной области дети иногда ничем не отличаются в другой от своих одноклассников. Однако, как правило «талантливый человек талантлив во всем». Высокая исследовательская активность и любознательность - это отличительный признак одаренных детей. Психофизиологические исследования показали, что у таких детей повышена электрическая и биохимическая активность мозга. Такие дети воспринимают недостаток информации болезненно. Если их постоянно ограничивать их активность, то это может вылиться в негативные реакции невротического характера.

У них ухудшается сон, меняется настроение. В этом возрасте дети могут делать выводы, прослеживать причинно-следственные связи, их увлекает построение моделей, систем. Одаренные дети обладают отличной памятью, абстрактным мышлением. Они способны распределять и классифицировать информацию на категории, использовать накопленные знания на практике.

Характерен большой словарный запас, так как они овладели речью на ранних этапах своего развития. Например: посетив одну и ту же экскурсию, обычный ребенок описывает свое впечатление несколькими предложениями, а одаренный ребенок с увлечением рассказывает малейшие детали, названия увиденных картин, улиц, соборов и т. д.

Повышенная концентрация внимания, это еще одна из способностей таких детей, они упорны в достижении результата. Однако разнообразие интересов приводит к тому, что они выполняют несколько дел одновременно или берутся за слишком сложное. Часто это приводит к тому что, если что-то не получается, то вызывает приступ паники, срыв и истерику. Нужно обращать внимание на резкое изменение поведения ребенка. Помочь ему справится с этими эмоциями. Так же присутствуют ситуации, когда одаренный в одной области ребенок не может выполнить простое задание в другой. Например, одаренный в исследовательской деятельности ребенок не может наклеить элементарную аппликацию, хотя легко справляется со сложными в сборке конструкциями объемных фигур и это приводит его в истерику. Он отказывается вообще выполнять работу, иногда даже плачет, но результат им непременно должен быть достигнут, так как это 
для него важно. Поэтому необходимо иногда менять учебную задачу для этого ребенка в ходе урока.

Работа педагога с одаренными детьми тесно связана с психологами. Ёе можно вести в 3 направлениях: развития интеллектуальных способностей ребенка, формирования адекватного самовосприятия, помощь в адаптации ребенка в окружающем мире и приобретение им конструктивных форм диалога со сверстниками и взрослыми. Требуется помочь родителям, педагогам и самому ребенку правильно организовать учебную деятельность. Сегодня формируют специальные программы для работы с одаренными детьми, школы во многих странах перестраиваются в сторону дифференцированного обучения. Наиболее известные программы работы с одаренными детьми: методика полного усвоения Дж. Кэррол и Б. Блум, программа С. Каплан, педагогика индивидуализации Р. Кузине, «Свободный класс» Гилфорда, «Три вида обогащения учебной программы» Рензулли и «Таксономия целей обучения» Блума.

Цели же практикующего педагога, человека изо дня в день работающего с детьми выстроить свою работу, исходя из предложенных методик, и главное, своевременно, аккуратно и грамотно корректировать ее.

Сейчас нет комплексной диагностики, позволяющей определить общую и специфическую одаренность, склонность ребенка к тому или иному виду творчества. Одаренность обнаруживается только тогда, когда ей каким-то образом удалось проявиться и закрепиться. Еще не полностью учитывается тот факт, что в силу личностных особенностей одаренные дети наиболее чувствительны к неадекватным оценкам, несправедливым и негативным воздействиям. В этой области имеется дефицит знаний об особенностях поведения и мышления одаренных детей, их личностном развитии и воспитании. Именно одаренные люди способны внести наибольший вклад в развитие общества.

\section{Список литературы}

1. Тимофеева (Напалкова) А.В. Особенности воспитания одарённых детей [Электронный ресурс]. - Режим доступа: https://infourok.ru/osobennostivospitaniya-odaryonnih-detey-1683973.html (дата обращения: 27.03.2018). 